\title{
FACTORS AFFECTING THE QUALITY OF LIFE IN CHRONIC OBSTRUCTIVE PULMONARY DISEASE PATIENTS AT FATMAWATI HOSPITAL, JAKARTA
}

\author{
Isman Setiawan, Asysyukriati R. Prawiro, Sri Wahyuningsih \\ Faculty of Medicine, UPN “Veteran”, Jakarta
}

\begin{abstract}
Background: Chronic obstructive pulmonary disease (COPD) is a major cause of morbidity and mortality worldwide including Indonesia with an increasing prevalence. Many factors can affect the quality of life in COPD patients. There is a lack of studies estimating these factors in Indonesia. This study aimed to analyze the factors affecting the quality of life of COPDpatients.

Subjects and Method: This was a cross-sectional study conducted at Fatmawati Hospital, Jakarta, from February to March 2017. A sample of 36 COPD patients was selected for this study. The dependent variable was quality of life. The independent variables were sex, age, education, employment, body mass index, lung obstruction level, and smoking history. Quality of life was measured by COPD Assessment Test (CAT) questionnaire. Lung obstruction level was measured by spirometry and classified by Global Initiative for Chronic Obstructive Lung Disease (GOLD) 2016. The other variables were collected by questionnaire. The data were analyzed by a multiple logistic regression.

Results: The quality of life of COPD patients decreased with higher body mass index $(\mathrm{OR}=7.29 ; 95 \% \mathrm{CI}=0.98$ to $54.27 ; \mathrm{p}=0.006)$, heavier pulmonary obstruction $(\mathrm{OR}=21.00 ; 95 \% \mathrm{CI}=2.026$ to $217.64 ; \mathrm{p}<0.001)$, older age $(\mathrm{OR}=$ $2.25,95 \% \mathrm{CI}=0.24$ to $21.54 ; \mathrm{p}=0.011)$, and smoking history $(\mathrm{OR}=1.58 ; 95 \% \mathrm{CI}=$ 0.153 to $16.32 ; \mathrm{p}=0.010$ ).

Conclusion: The quality of life of COPD patients is affected by body mass index, degree of pulmonary obstruction, age, and smoking history
\end{abstract}

Keywords: quality of life, chronic obstructive pulmonary disease, determinant

\section{Corespondence:}

Sri Wahyuningsih. Faculty of Medicine, UPN "Veteran", Jakarta.

Email: ismansetiawan@gmail.com. Mobile: 081287552465. 